\title{
Phylogenetic Analysis of Symbiotic Bacteria Associated with Two Vigna Species under Different Agro-Ecological Conditions in Venezuela
}

\author{
María Daniela Artigas Ramírez ${ }^{1}$, Mingrelia España ${ }^{2}$, Sylwia Lewandowska ${ }^{3}$, Kun Yuan ${ }^{1}$, Shin Okazaki $^{4}$, \\ NaOKo OHKAMA-OHtsu ${ }^{1,5}$, and TADASHi YoKoYAMA ${ }^{5 *}$ \\ ${ }^{1}$ Institute of Global Innovation Research, Tokyo University of Agriculture and Technology (TUAT), Saiwai-cho 3-5-8, Fuchu, \\ Tokyo-Japan; ${ }^{2}$ Institute for Advanced Studies (IDEA), Miranda-Venezuela; ${ }^{3}$ Department of Genetics, Plant Breeding and Seed \\ Production, Wrocław University of Environmental and Life Sciences, 50-363 Wrocław, 24A, Grunwaldzki-Poland; ${ }^{4}$ United \\ Graduated School of Agriculture, Tokyo University of Agriculture and Technology (TUAT), Saiwai-cho 3-5-8, Fuchu, Tokyo- \\ Japan; and ${ }^{5}$ Institute of Agriculture, Tokyo University of Agriculture and Technology (TUAT), Saiwai-cho 3-5-8, Fuchu, Tokyo- \\ Japan
}

(Received September 21, 2019 - Accepted November 10, 2019_Published online January 11, 2020)

Vigna is a genus of legumes cultivated in specific areas of tropical countries. Species in this genus are important crops worldwide. Vigna species are of great agronomic interest in Venezuela because Vigna beans are an excellent alternative to other legumes. However, this type of crop has some cultivation issues due to sensitivity to acidic soils, high temperatures, and salinity stress, which are common in Venezuela. Vigna species establish symbioses mainly with Bradyrhizobium and Ensifer, and Vigna-rhizobia interactions have been examined in Asia, Africa, and America. However, the identities of the rhizobia associated with $V$. radiata and $V$. unguiculata in Venezuela remain unknown. In the present study, we isolated Venezuelan symbiotic rhizobia associated with Vigna species from soils with contrasting agroecosystems or from fields in Venezuela. Several types of soils were used for bacterial isolation and nodules were sampled from environments characterized by abiotic stressors, such as high temperatures, high concentrations of $\mathrm{NaCl}$, and acidic or alkaline $\mathrm{pH}$. Venezuelan Vigna-rhizobia were mainly fast-growing. Sequencing of several housekeeping genes showed that in contrast to other continents, Venezuelan Vigna species were nodulated by rhizobia genus including Burkholderia, containing bacteria from several new phylogenetic lineages within the genus Bradyrhizobium. Some Rhizobium and Bradyrhizobium isolates were tolerant of high salinity and $\mathrm{Al}$ toxicity. The stress tolerance of strains was dependent on the type of rhizobia, soil origin, and cultivation history. An isolate classified as $R$. phaseoli showed the highest plant biomass, nitrogen fixation, and excellent abiotic stress response, suggesting a novel promising inoculant for Vigna cultivation in Venezuela.

Key words: Ensifer, V. unguiculata, Burkholderia, Bradyrhizobium, Venezuela

Vigna is a genus in the legume family (Fabaceae), and some of the oldest crops known to man belong to the genus Vigna. Vigna originated in Africa and were introduced to the Americas from Eastern Africa in 1500 AD (Doyle, 1994). They are essential nutritional legumes, and a valuable component of the traditional cropping systems found in semiarid tropical regions, such as Asia, Africa, and Central and South America (Singh et al., 1997; Zhang et al., 2008; Sarr et al., 2011). There are approximately 11 million hectares under Vigna cultivation worldwide. Asian countries are responsible for the majority of global Vigna production, accounting for $90 \%$ of 5.8 million tons of Vigna beans annually (Zhang et al., 2008; Risal et al., 2012).

Vigna is a widespread genus and is part of the thirdlargest family of flowering plants (Fabaceae) (Allen and Allen, 1981; Doyle, 1994; Lambrides and Godwin, 2007). Legume members of Vigna consist of approx. 20,000 species (Doyle, 1994). This genus contains several species that are important in the agricultural world, such as mung beans ( $V$. radiata), cowpea ( $V$. unguiculata), adzuki beans ( $V$. angularis), urad beans ( $V$. mungo), rice beans ( $V$. umbellata), moth beans ( $V$. aconitifolia), and bambara groundnut ( $V$.

\footnotetext{
* Corresponding author. E-mail: tadashiy@cc.tuat.ac.jp;
}

Tel: +81-423675878; Fax: +81-423675878. subterranea) (Lambrides and Godwin, 2007). In Venezuela, there is great diversity in Vigna cultivars, including $V$. unguiculata and $V$. radiata, which are important components of the Venezuelan diet (Vásquez, 2014). These species are commonly called "Frijol bayo" or "Frijol chino" in local colloquial language (Vásquez, 2014). Vigna legumes are a good alternative to other legumes present in the Venezuelan diet. V. unguiculata is of great agronomic interest due to its resistance to soil acidity, drought, and high temperatures (Timko et al., 2007; Li et al., 2009). However, V. radiata may develop major issues during cultivation in Venezuela due to its low tolerance to high temperatures, drought, and some edaphological conditions, which reduce production, in addition to disease and pest problems (Lambrides and Godwin, 2007; Vásquez, 2014).

Vigna-nodulating rhizobia are genetically diverse (Risal et al., 2012). They were previously characterized as slowgrowing bradyrhizobia (Allen and Allen, 1981). Vigna has been characterized for establishing symbioses in most countries, mainly with bradyrhizobia. These bradyrhizobialegume interactions have been examined in Asia, Africa, and the Americas (Lambrides and Godwin, 2007; Risal et al., 2012). Recent studies reported that some Vigna species also successfully establish $\mathrm{N}_{2}$-fixing symbiosis with Ensifer and Rhizobium species (Lu et al., 2009; Ren et al., 2011; 
Risal et al., 2012; Andrews and Andrews, 2017). However, some rhizobia, such as Mesorhizobium, Burkholderia, and Microvirga, display host specificity with Vigna (Lu et al., 2009; Radl et al., 2014; Andrews and Andrews, 2017).

In Venezuela, the rhizobia genetically associated with Sesbania sp. have been characterized as Leucaena sp., Medicago sativa, and Phaseolus vulgaris (Vinuesa et al., 2005; Marquina et al., 2011). In 2018, Venezuelan soybean rhizobia were characterized and belonged to Rhizobium with a predominance of the genus Burkholderia (Artigas et al., 2019). However, Vigna-rhizobia symbiosis has not yet been examined under Venezuelan environmental conditions. The present study was conducted to elucidate the genetic diversity and geographical distribution of Vigna-rhizobia under different Venezuelan agro-conditions as well as the symbiotic functioning of Venezuelan isolates and Vigna species. The results obtained may contribute to the search for the best bacteria for crop inoculation and increased crop production under Venezuelan conditions.

\section{Materials and Methods}

\section{Collection sites and soil samples}

Soil samples were collected from 10 Venezuelan regions and root nodules were picked up from 3 areas in which Vigna had previously been cultivated (Fig. 1 and Table 1). These areas were located in diverse agroecological regions with contrasting climates, topographies, and soils (Table 1). Soil samples from each area were a composite of 2 sub-samples prepared by mixing soils obtained from depths of $0-20 \mathrm{~cm}$. No bacterial inoculations had previously been performed in these areas. Therefore, these strains were considered to be indigenous to Venezuela. Furthermore, soil samples were collected from different types of soils, including Alfisol, Oxisol, Inceptisol, Aridisol, Ultisol, and Vertisol (Table 1).

Isolation of rhizobia from Venezuelan soils using Vigna species as trap hosts

Two types of Vigna species were used in the present study: the cowpea $V$. unguiculata cultivar 'Tuy' (Venezuelan variety) and the mung bean $V$. radiata cultivar 'Ryokutou' (Japanese variety). $V$. unguiculata and $V$. radiata were used in inoculation tests (pot tests) with soils from different agroecological conditions. Seeds were surface-sterilized and inoculated with 5-fold dilutions of soil suspensions (Risal et al., 2012). After the seeds were sown, plants were grown in a growth room chamber under sterile conditions. A sterilized nitrogen-free nutrient solution (Somasegaran and Hoben, $1994)$ was added to the glass jars $(300 \mathrm{~mL})$. A moisture level of $60 \%$ of the water field capacity was established and maintained throughout the growth period. Plants were grown for 4 weeks in the growth chamber under a 16-h light (5,000 7,000 LUX) and 8-h dark photoperiod at $28^{\circ} \mathrm{C}$. After four weeks, the root nodules were collected and washed with sterile distilled water. $V$. unguiculata root nodules were also harvested from field conditions (as dried nodules, Table 1).

The root nodules were sterilized as described previously (Artigas et al., 2019). After sterilization, the root nodules were washed with sterile distilled water 4 times. Surface-sterilized root nodules were crushed in $500 \mu \mathrm{L}$ glycerol solution $(15 \%$ [v/v]) to obtain a bacterial suspension. An aliquot $(10 \mu \mathrm{L})$ of the suspension was streaked (Vincent, 1970) onto 1.5\% (w/v) Yeast Mannitol agar (YMA) medium (Somasegaran and Hoben, 1994). The agar plates were then incubated at $28^{\circ} \mathrm{C}$ for one week. The remaining suspension was frozen at $-80^{\circ} \mathrm{C}$ for further isolations, if necessary. Single colonies were restreaked onto fresh agar plates to obtain pure colonies. Phenotypically, the strains were characterized in terms of their growth rate, texture, and color on YMA plates. These isolates were re-inoculated onto the host plant to verify their nodulation abilities.

\section{Stress tolerance screening}

Isolates were evaluated for growth under different abiotic stress conditions: high temperature, alkaline $\mathrm{pH}$, acidic $\mathrm{pH}$, high salinity, and a high concentration of aluminum (Al) at different $\mathrm{pHs}$. The temperature tolerance of isolates was tested by recording their ability to grow under the following temperatures: 25, 28 (control), 35, and $40^{\circ} \mathrm{C}$ on YMA plates. Regarding $\mathrm{pH}$ tolerance, the abilities of isolates to grow at different $\mathrm{pHs}$ was tested under the following $\mathrm{pH}$ conditions: 4.5, 5, 6.8 (control), 8, and 10 (Somasegaran and Hoben, 1994). These tests were performed on YMA plates with $\mathrm{pH}$ adjusted by $0.5 \mathrm{M} \mathrm{HCl}$ or $0.5 \mathrm{M} \mathrm{NaOH}$. The salinity and $\mathrm{Al}$ toler-

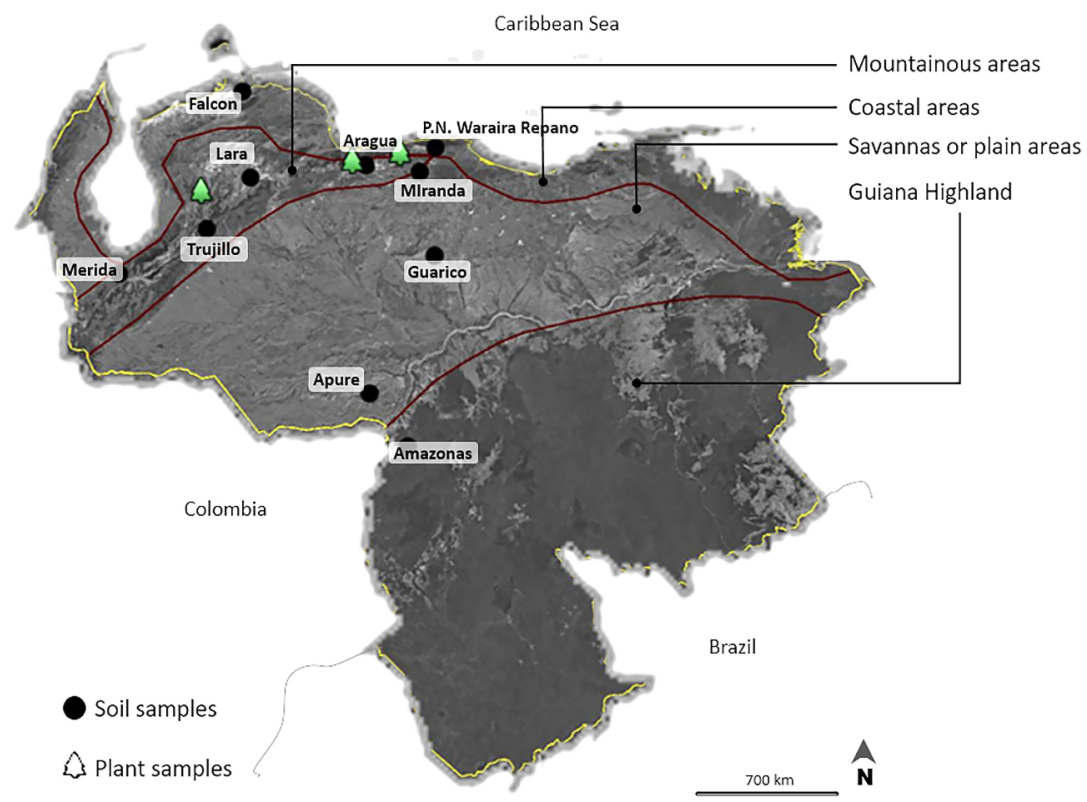

Fig. 1. Map of Venezuela showing different agro-ecological regions for collection sites, and geographical locations of soil and plant samples used for rhizobial isolation (This map was made by Google earth Pro software). 
Table 1. General characteristics of soil sampling and nodule numbers on Vigna

\begin{tabular}{|c|c|c|c|c|c|c|c|c|c|c|c|c|}
\hline \multirow{2}{*}{ Origin } & \multirow{2}{*}{$\begin{array}{l}\text { State } \\
\text { (Sites) }\end{array}$} & \multirow{2}{*}{$\begin{array}{l}\text { Cardinal } \\
\text { location }\end{array}$} & \multirow{2}{*}{ Ecosystem } & \multirow{2}{*}{ Soil type } & \multirow{2}{*}{$\mathrm{pH}^{\mathrm{a}}$} & \multirow{2}{*}{$\begin{array}{l}\text { Temp. } \\
\left({ }^{\circ} \mathrm{C}\right)^{b}\end{array}$} & \multirow{2}{*}{$\underset{(\mathrm{ppm})^{\mathrm{c}}}{\mathrm{Al}}$} & \multirow{2}{*}{ Vegetation } & \multicolumn{2}{|c|}{$\begin{array}{c}\text { Total number } \\
\text { nodules onVigna }\end{array}$} & \multicolumn{2}{|c|}{$\begin{array}{c}\text { Total strains } \\
\text { isolated fromVigna }\end{array}$} \\
\hline & & & & & & & & & unguiculata & radiata & unguiculata & radiata \\
\hline \multirow{11}{*}{$\begin{array}{c}\text { Soils } \\
\text { (Pot test) }\end{array}$} & Amazonas & South & $\begin{array}{l}\text { Jungle/rain- } \\
\text { forest }\end{array}$ & Oxisol* & $5.5 \sim 6.0$ & $12 \sim 33$ & 0.25 & $\begin{array}{c}\text { Cucumber, tomato, coriander, } \\
\text { Capsicum sp. Phaseolus sp., } \\
\text { Fabaceae* }\end{array}$ & 32 & 22 & 20 & 12 \\
\hline & Apure & Southwest & Floodplain & Inceptisol & $4.2 \sim 5.0$ & $10 \sim 34$ & 2.25 & $\begin{array}{c}\text { Acacia sp., Caraipa sp., } \\
\text { Mauritia sp. Tabebuia sp., and } \\
\text { Fabaceae* }\end{array}$ & 22 & 0 & 17 & 0 \\
\hline & Aragua & North-central & $\begin{array}{l}\text { Valley No } \\
\text { Fertilizer }\end{array}$ & Inceptisol & $7.1 \sim 7.5$ & \multirow{2}{*}{ 18 31 } & 0.00 & $\begin{array}{c}\text { Sesamun sp., Vigna sp., Arachis } \\
\text { sp., Canajus sp. }\end{array}$ & 52 & 20 & 15 & 3 \\
\hline & Aragua & North-central & $\begin{array}{l}\text { Valley with } \\
\text { Fertilizer }\end{array}$ & Inceptisol & $7.5 \sim 8.0$ & & 0.00 & $\begin{array}{c}\text { Asteracea sp., Phaseolus sp., } G \text {. } \\
\text { max, grasses }\end{array}$ & 56 & 23 & 16 & 15 \\
\hline & $\begin{array}{c}\text { DC } \\
\text { (Caracas) }\end{array}$ & North-central & $\begin{array}{l}\text { National Park } \\
\text { in City }\end{array}$ & Alfisol & $5.6 \sim 6.5$ & $10 \sim 31$ & 3.75 & $\begin{array}{l}\text { Coffea sp., sugarcane, tree } \\
\text { forest, Bryophytes, Fabaceae* }\end{array}$ & 44 & 0 & 22 & 0 \\
\hline & Falcón & Northwest & Arid-desert & Aridisol & $8.0 \sim 10$ & $22 \sim 40$ & 1.13 & Prosopis sp., Opuntia sp. & 33 & 17 & 16 & 15 \\
\hline & Guárico & Central & Savanna & Vertisol & $5.8 \sim 6.5$ & $25 \sim 35$ & 0.00 & Cereals, Fabaceae* & 21 & 14 & 20 & 6 \\
\hline & Lara & West-central & Dried savanna & Vertisol & $6.0 \sim 6.3$ & $10 \sim 34$ & 0.38 & $\begin{array}{c}\text { Coffea sp., Inga sp., grasses, } \\
\text { Phaseolus sp. }\end{array}$ & 29 & 14 & 16 & 18 \\
\hline & Mérida & Southwest & $\begin{array}{l}\text { Andes- } \\
\text { Template }\end{array}$ & Ultisol & $4.4 \sim 5.0$ & $6 \pm 24$ & 3.50 & $\begin{array}{c}\text { Musa sp., Lactuca sp., } \\
\text { Theobroma sp., forestal species, } \\
\text { Phaseolus sp. }\end{array}$ & 38 & 24 & 17 & 12 \\
\hline & Miranda & Central coast & Mountain & Alfisol & $5.6 \sim 6.0$ & $10 \sim 33$ & 0.00 & $\begin{array}{l}\text { Tree species of humid forest as } \\
\text { Pseudobombax, Fabaceae* }\end{array}$ & 37 & 14 & 19 & 10 \\
\hline & Trujillo & Northwest & Andes & Ultisol & $3.6 \sim 4.5$ & $10 \sim 24$ & 20.38 & Theobroma sp., Inga edulis & 11 & 0 & 9 & 0 \\
\hline \multirow{4}{*}{$\begin{array}{l}\text { Root nodules } \\
\text { from the field in } \\
\text { Venezuela }\end{array}$} & Aragua & \multirow{2}{*}{$\begin{array}{l}\text { North-central } \\
\text { coast }\end{array}$} & $\begin{array}{l}\text { Valley No } \\
\text { Fertilizer }\end{array}$ & Inceptisol & $7.1 \sim 7.5$ & \multirow{2}{*}{$18 \sim 31$} & 0.00 & Sorghum sp., grasses, Vigna & 45 & 0 & 5 & 0 \\
\hline & Aragua & & $\begin{array}{l}\text { Valley with } \\
\text { Fertilizer }\end{array}$ & Inceptisol & $7.5 \sim 8.0$ & & 0.00 & Asteracea species, Phaseolus & 35 & 0 & 1 & 0 \\
\hline & Trujillo & Northwest & Andes & Ultisol & $3.6 \sim 4.5$ & $10 \sim 24$ & 20.38 & $\begin{array}{c}\text { Coffea arabica, Zea sp., } \\
\text { Fabaceae* }\end{array}$ & 20 & 0 & 3 & 0 \\
\hline & & & & & & & & Total & 475 & 148 & 196 & 91 \\
\hline
\end{tabular}

a: These values were reported by Casanova (2005) and confirmed using a standard pH soil method (Jones, 2001; Casanova, 2005).

b: Temperature average reported by REDBC and INIA-Venezuela.

c: Al ${ }^{3+}$ method (Hsu, 1963; Jones, 2001). *: Amazon soil is classified as Entisol and Oxisol; however, the sampling site was Oxisol.

Fabaceae*: It includes non-cultivated plants and unknown genera of trees, shrubs, and perennial or annual herbaceous plants.

ance of isolates were assessed as described previously (Artigas et al., 2019). The isolates were initially grown in YM broth for five $\mathrm{d}$ at $28^{\circ} \mathrm{C}$, and $5 \mu \mathrm{L}$ of cell suspensions at $10^{9}$ cells $\mathrm{mL}^{-1}$ were ten transferred to YMA plates and YM broth under stress conditions at $28^{\circ} \mathrm{C}$ for $4-10 \mathrm{~d}$. The growth of strains on YMA was estimated relative to the control treatment, as described previously (Artigas et al., 2019).

\section{Plant tests for symbiosis analysis}

A total of 120 isolates were selected as representatives of diverse groups from abiotic stress tolerance assays, which included sensitive and tolerant strains. Pre-selected isolates were grown in $\mathrm{YM}$ broth for five $\mathrm{d}$ at $28^{\circ} \mathrm{C}$ to obtain $10^{7}$ cells $\mathrm{mL}^{-1}$, as described previously (Vincent, 1970). Prior to the inoculation, the seeds of $V$. unguiculata 'Tuy' were surface-sterilized with $70 \%$ ethanol for $30 \mathrm{~s}, 3 \%(\mathrm{v} / \mathrm{v})$ of sodium hypochlorite for $2 \mathrm{~min}$, and then washed 4 times with sterile distilled water. Seeds were then inoculated by soaking in these rhizobial cells at $10^{7}$ cells $\mathrm{mL}^{-1}$ and sown on $200 \mathrm{~g}$ of vermiculite (Vermitech) in a plant box $(7.6 \times 7.6 \times 10.2 \mathrm{~cm})$. A sterilized nitrogen-free nutrient solution (Sylvester-Bradley et al., 1983) was added to vermiculate to reach a moisture level that was $60 \%$ of the field capacity, and this level was maintained throughout the growth period. Plants were cultivated for $30 \mathrm{~d}$ in the growth chamber (FLI 2000-EYELA; Tokyo Rikakikai Corporation, Tokyo, Japan) under a 16 -h light $/ 8$-h dark photoperiod at $28^{\circ} \mathrm{C}$. Three replicates per strain were performed for all treatments, and one replicate contained one plant per plant box. Non-inoculated plants served as control treatments (Vincent, 1970). To obtain an accurate mass, these root nodules, shoots, and roots were dried at $80^{\circ} \mathrm{C}$ for $48 \mathrm{~h}$ before weighing.

\section{Nitrogenase activity}

Intact plants with root nodules were collected after $30 \mathrm{~d}$ of culture for nitrogen fixation assessments using an acetylene reduction assay (ARA). ARA was performed using a Shimadzu gas chromatograph GC-2014 gas chromatograph (Shimadzu Corporation, Kyoto, Japan) equipped with a Porapak N column (Agilent Technologies, Santa Clara, USA). Whole root systems of Vigna plants were placed into an incubation bottle $(300 \mathrm{~mL})$ with a sealed cap, and $10 \%(\mathrm{v} / \mathrm{v})$ of the air was replaced with acetylene gas. Samples were incubated at $28^{\circ} \mathrm{C}$ for $30-40 \mathrm{~min}$. After the incubation, $1 \mathrm{~mL}$ of the gas sample was injected into the gas chromatograph, and this was followed by the assessment of root nodule numbers. The masses of shoots, roots, and root nodules were measured after they were dried at $80^{\circ} \mathrm{C}$ for $48 \mathrm{~h}$.

\section{Statistical analysis}

Statistical analyses were performed with Tukey's and Dunnett's tests using Statistica software version 12.0 (StatSoft, Tulsa, USA). A value of $P \leq 0.05$ was considered to be significant.

\section{Isolation of genomic DNA}

Forty-six isolates were selected based on their symbiotic performance and tolerance to abiotic stress. DNA was extracted from isolates grown in $\mathrm{YM}$ broth medium at $28^{\circ} \mathrm{C}$ for four $\mathrm{d}$. Prior to DNA isolation, cells were collected and washed twice with equal volumes of TE buffer. Total genomic DNA was extracted as described previously (Artigas et al., 2019). 


\section{DNA amplification and sequencing}

PCR amplification and sequencing of 16S rRNA, atpD, nod, and nif gene regions were performed as described previously (Risal et al., 2012). The primer sets used for the PCR of 16S rRNA and nodD genes were described previously (Risal et al., 2012). The $a t p D$ (ATP synthase) primer set used was described by Gaunt et al. (2001). The nifH primer set for the nif gene was described previously by Laguerre et al. (2001). Amplifications were performed as described by Artigas et al. (2019). Thermal cycling conditions were as follows: denaturation at $95^{\circ} \mathrm{C}$ for $4 \mathrm{~min}, 35$ cycles of denaturation at $94^{\circ} \mathrm{C}$ for $1 \mathrm{~min}$, annealing at 60 or $55^{\circ} \mathrm{C}$ for $45 \mathrm{~s}$, and extension at $72^{\circ} \mathrm{C}$ for $2 \mathrm{~min}$, followed by a final extension at $72^{\circ} \mathrm{C}$ for $5 \mathrm{~min}$. Amplifications were performed using a thermal cycler (GeneAmp PCR system 9700; Applied Biosystems, Waltham, USA). PCR products were checked using agarose gels, and DNA was purified using a Fast Gene Gel/PCR extraction kit (Nippon Genetics, Tokyo, Japan) for all genes. PCR products were sequenced using an ABI Prism 3500 Genetic Analyzer (Applied Biosystems), according to the manufacturer's protocol. The sequences obtained were compared with the corresponding genes deposited in the GenBank database (https://www.ncbi.nlm.nih.gov/ genbank/) using the online software BLAST algorithm-based sequence alignment. Phylogenetic trees were constructed using the software Genetix version 11 and MEGA version 6.0 (Tamura et al., 2013).

\section{Accession numbers}

The gene sequences obtained in the present study were deposited in the DNA Databank of Japan (DDBJ) under accession numbers LC460871 to LC460916 (16S rRNA), LC460917 to LC460962 (atpD gene), LC461082 to LC461127 (nifH gene), and LC461128 to LC461173 (nodD gene).

\section{Results}

\section{Characterization of Vigna rhizobia isolated from different Venezuelan soils}

The characteristics of soils used for rhizobia-isolation included $\mathrm{Al}$ concentrations shown in Table 1. In the present study, acidic soils were taken from the Venezuelan Andes (Trujillo and Mérida sites). Trujillo was the sampling site with the highest $\mathrm{Al}$ concentration and lowest $\mathrm{pH}$ in this study. Venezuelan savannas, located in Guárico and Apure, also had low pH. Additionally, the rainforest of the Amazonas State possessed Oxisol with an acidic pH. Guárico and Falcón showed the highest temperatures of approximately $\geq 35^{\circ} \mathrm{C}$ (Table 1 ).

The total number of root nodules was 623 , with 523 being harvested from pot experiments with soils and 100 collected from field-grown Vigna species (Valley and Andes sites, Table 1). Among the Vigna plants used as trap hosts, 475 root nodules were obtained from the Venezuelan 'Tuy' cultivar of $V$. unguiculata (cowpea) and 148 were harvested from the Japanese 'Ryokutou' cultivar $V$. radiata (mung bean), as shown in Table 1. The Aragua-Valley, located in northcentral Venezuela, was classified as an area that cultivated crops with or without the application of inorganic fertilizers (Table 1). This sampling site produced the most abundant root nodules. We sampled 54 root nodules from the Amazonas site, located in the rainforest ecosystem. This site is located in the Guiana Highlands, which traditionally produces crops such as cucumber, tomato, and coriander. It is important to note that $V$. radiata showed no nodulation at the Apure, DC, and Trujillo sites. In Aragua and Trujillo, 9 strains of $V$. unguiculata were successfully isolated from dried nodules (field collection). A total of 287 strains were isolated from both Vigna species (Table 1).

\section{Physiological characterization of Vigna rhizobia under abiotic stress conditions}

The physiological properties of the 287 isolates were evaluated under abiotic stress. Furthermore, a representative group of isolates (120 strains) was selected according to their tolerance of and sensitivity to different abiotic stresses (Table 2 and S1). The growth rates of these isolates were classified into two groups: fast growers represented $41 \%$ and intermediate growers 59\% (Table S1). Isolates were distinguished phenotypically by morphological characteristics, such as color and texture. Total isolates were classified into four types according to color: being predominant whitetransparent color (WT; $n=102$ ). Accordingly, the strains were dominant by a creamy texture in 104 isolates (Table S1).

Strains showed different abilities to grow under hightemperature conditions. Eighty-seven percent of isolates were able to grow at $40^{\circ} \mathrm{C}$, showing high-temperature tolerance (Table $\mathrm{S} 1$ ). In the case of salinity tolerance, all isolates grew similar to or better than the control $(0 \%)$ at $1 \% \mathrm{NaCl}$. Nine isolates $(3 \%$ of the total) did not grow at the same rate

Table 2. Number of isolates selected for different analyses and their distribution under different Venezuelan agro-conditions.

\begin{tabular}{|c|c|c|c|c|c|c|}
\hline \multirow{2}{*}{ State (Sites) } & \multirow{2}{*}{ Soil type } & \multirow{2}{*}{$\begin{array}{l}\text { For abiotic } \\
\text { stress }\end{array}$} & \multicolumn{2}{|c|}{ For phylogenetic analysis } & \multicolumn{2}{|c|}{ Bacterial classes } \\
\hline & & & V. unguiculata & V. radiata & $\alpha$-Proteobacteria & $\beta$-Proteobacteria \\
\hline Amazonas & Oxisol & 10 & 3 & 2 & 5 & 0 \\
\hline Apure & Inceptisol & 10 & 4 & 0 & 4 & 0 \\
\hline Aragua & Inceptisol & 13 & 4 & 0 & 4 & 0 \\
\hline Aragua & Inceptisol & 10 & 3 & 1 & 4 & 0 \\
\hline DC (Caracas) & Alfisol & 10 & 2 & 0 & 2 & 0 \\
\hline Falcón & Aridisol & 9 & 4 & 1 & 4 & 1 \\
\hline Guárico & Vertisol & 12 & 4 & 2 & 4 & 2 \\
\hline Lara & Vertisol & 15 & 2 & 2 & 3 & 1 \\
\hline Mérida & Ultisol & 12 & 3 & 2 & 5 & 0 \\
\hline Miranda & Alfisol & 10 & 2 & 1 & 3 & 0 \\
\hline \multirow[t]{2}{*}{ Trujillo } & Ultisol & 9 & 4 & 0 & 4 & 0 \\
\hline & Total & 120 & 35 & 11 & 42 & 4 \\
\hline
\end{tabular}


with $2 \% \mathrm{NaCl}$, and also did not grow under 3 and $4 \% \mathrm{NaCl}$. Ninety-five percent of isolates tolerated high concentrations of $\mathrm{NaCl}(4 \%)$. Some isolates grew under 3 and $4 \% \mathrm{NaCl}$ conditions and grew similar to or better than the control $(0 \%$ $\mathrm{NaCl}$ ). At $4 \% \mathrm{NaCl}$, the isolates from Apure (10 isolates), Guárico (12 isolates), and Falcón (9 isolates) grew similar to the control. Two isolates from Amazonas (AmR5) and Aragua (valley with fertilizer) (AFV3) did not grow at $4 \%$ $\mathrm{NaCl}$ (Table S1).

Most of the strains were tolerant to alkaline conditions, but sensitive to acidic conditions. Eighteen percent of isolates did not grow under acidic conditions, whereas all isolates successfully grew under alkaline conditions; however, $2 \%$ showed weaker growth at $\mathrm{pH} 10$ than controls at $\mathrm{pH} 6.8$ (Table S1). In contrast, eight isolates did not survive under acidic conditions ( $\mathrm{pH} 4.5$ ), particularly those from alkaline soils, such as Falcón and Aragua. For example, two isolates from Merida and Trujillo showed weaker growth than the control ( $\mathrm{pH}$ 6.8). Similarly, the growth of isolates was severely inhibited at high Al concentrations, but was inhibited more under acidic $\mathrm{pH}$. Al toxicity is lower under neutral $\mathrm{pH}$ conditions because nearly $98 \%$ of isolates survive and grow under these conditions. Accordingly, isolates from soils with $\mathrm{Al}$ or acidic soils showed more tolerance to $\mathrm{Al}$ toxicity, such as Trujillo. Nine percent of isolates grew under a combination of $2 \mathrm{mM}$ of $\mathrm{Al}$ and $\mathrm{pH} 4.5$ (Table S1).

These isolates (120 strains) were inoculated into $V$. unguiculata seeds. However, only 46 isolates exhibited nodulation activity on $V$. unguiculata. The physiological characteristics of selected isolates are summarized in supplementary Table S1 (highlighted with positive nodulation activity). These nodulating isolates grew under high temperatures, high concentrations of $\mathrm{NaCl}$, and an alkaline $\mathrm{pH}$ (Table S1). Only two isolates did not survive in acidic soils: one strain from Aridisol (Falcon, FV3) and the other from Ultisol (Trujillo, TrV2B). Nine fast-grower isolates were Altolerant at $2 \mathrm{mM}$ combined with $4.5 \mathrm{pH}$. These isolates were subsequently analyzed according to their genetic characteristics and symbiotic performance.

\section{Distribution of rhizobia and phylogeny based on $16 S$ rRNA and atpD genes}

Forty-six isolates were analyzed using the 16S rRNA gene, their general taxonomic position, and their distribution, as shown in Table 2 . The phylogenetic analysis clearly showed that Venezuelan isolates clustered into two major groups of bacteria: $\alpha$-Proteobacteria and $\beta$-Proteobacteria (Table 2). These isolates were classified as follows: group I (GI) contained $58 \%$ of all isolates (42 $\alpha$-rhizobia), which were widely distributed in Venezuela, and group II (GII) included $\alpha$-rhizobia and $\beta$-rhizobia. Thirty-three percent of all isolates were classified as Bradyrhizobium, while the genus Burkholderia represented 9\% (Fig. 2). Their main distribution in Venezuela was as follows: strains from Aragua (Inceptisol soil) had a high level of Vigna-rhizobia (Table 2). Although, there is a specificity in Falcón (Aridisol) where the isolates were classified as Ensifer. Agrobacterium $/ R$. pusense included ten isolates from different ecosystems, such as template (Mérida) and rainforest (Amazonas). All isolates from Trujillo belonged to the genus

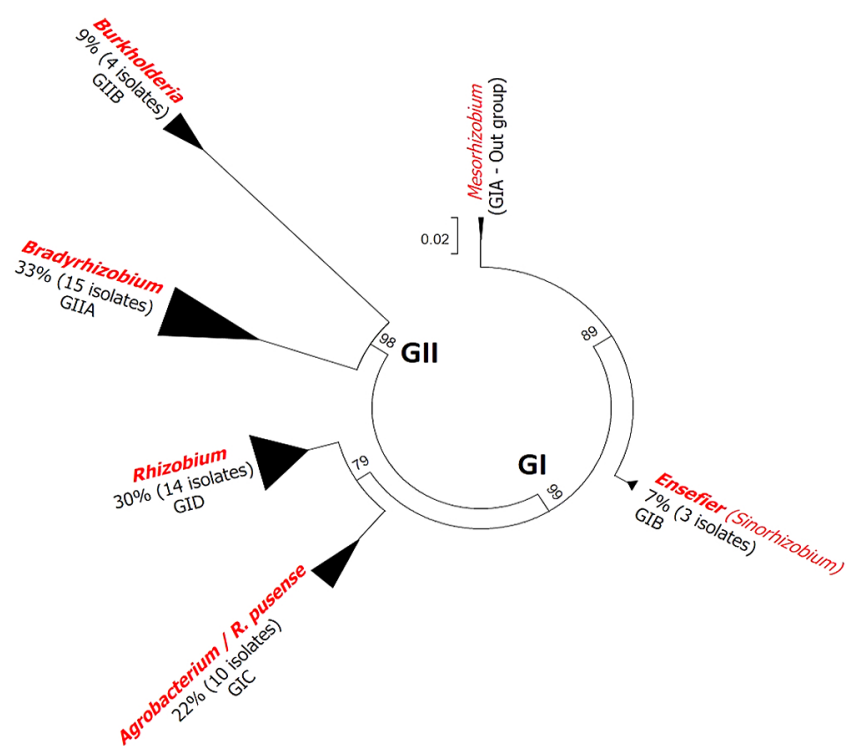

Fig. 2. General analysis based on $16 \mathrm{~S}$ rRNA sequences of Venezuela isolates. The phylogenetic tree included Vigna-rhizobia (46 isolates) and references of $\alpha$-rhizobia and $\beta$-rhizobia (38 reference strains). The tree is based on differences in 1,390-bp DNA fragments. The scale bar represents substitutions per nucleotide position and each genus included the percentage of total isolates. Numbers at the nodes indicate the level of bootstrap support $(\%)$, based on a neighbor-joining analysis of 1,000 re-sampled datasets.

Bradyrhizobium. $\beta$-rhizobia isolates were mainly from Vertisol (3 isolates) and one was from Aridisol (Table 2).

To confirm the results obtained, one housekeeping gene $(a t p D)$ was phylogenetically analyzed (Fig. 3). The results obtained were generally consistent with 16S rRNA gene results. Accordingly, Venezuelan isolates closely related to $\alpha$-rhizobia were mainly classified into the genera Rhizobium and Bradyrhizobium (Fig. 3 and S1). GI contained the outgroup Mesorhizobium, which did not have a close relationship with any isolates from this study. Three isolates were classified as E. mexicanus (GIA). GIB grouped different Rhizobium species and 14 Venezuelan isolates. The relationship between isolates and Rhizobium species was as follows: $R$. etli (4 isolates), $R$. phaseoli (4 isolates), $R$. vallis (1 isolate), $R$. tropici (2 isolates), and $R$. pisi (1 isolate), and one isolate included as Rhizobium sp. (Fig. S1). These results suggested that Agrobacterium and $R$. pusense were closely related, and these genera were grouped into the same clade (GIC) with Venezuelan isolates.

In the second group of Vigna-rhizobia isolates (GII), 15 isolates were classified as the genus Bradyrhizobium (GIIA). Four isolates had a close relationship with $B$. embrapense, while $B$. elkanii and B. pachyrhizi were also closely related to 3 isolates. Isolates within this sub-clade were closely related to $B$. rifense (1 isolate), $B$. yuanmingense ( 2 isolates), B. japonicum (1 isolate), and $B$. liaoningense (3 isolates). It is important to note that one isolate, $\operatorname{TrV} 5$, had no related reference strain, which suggests that this is a novel genospecies or symbiovar of Bradyrhizobium. In the case of $\beta$-rhizobia, isolates were closely related to Burkholderia species (GIIB). These isolates were related to Paraburkholderia symbiont and $P$. tuberum (Fig. S1). The last isolate had no related reference 


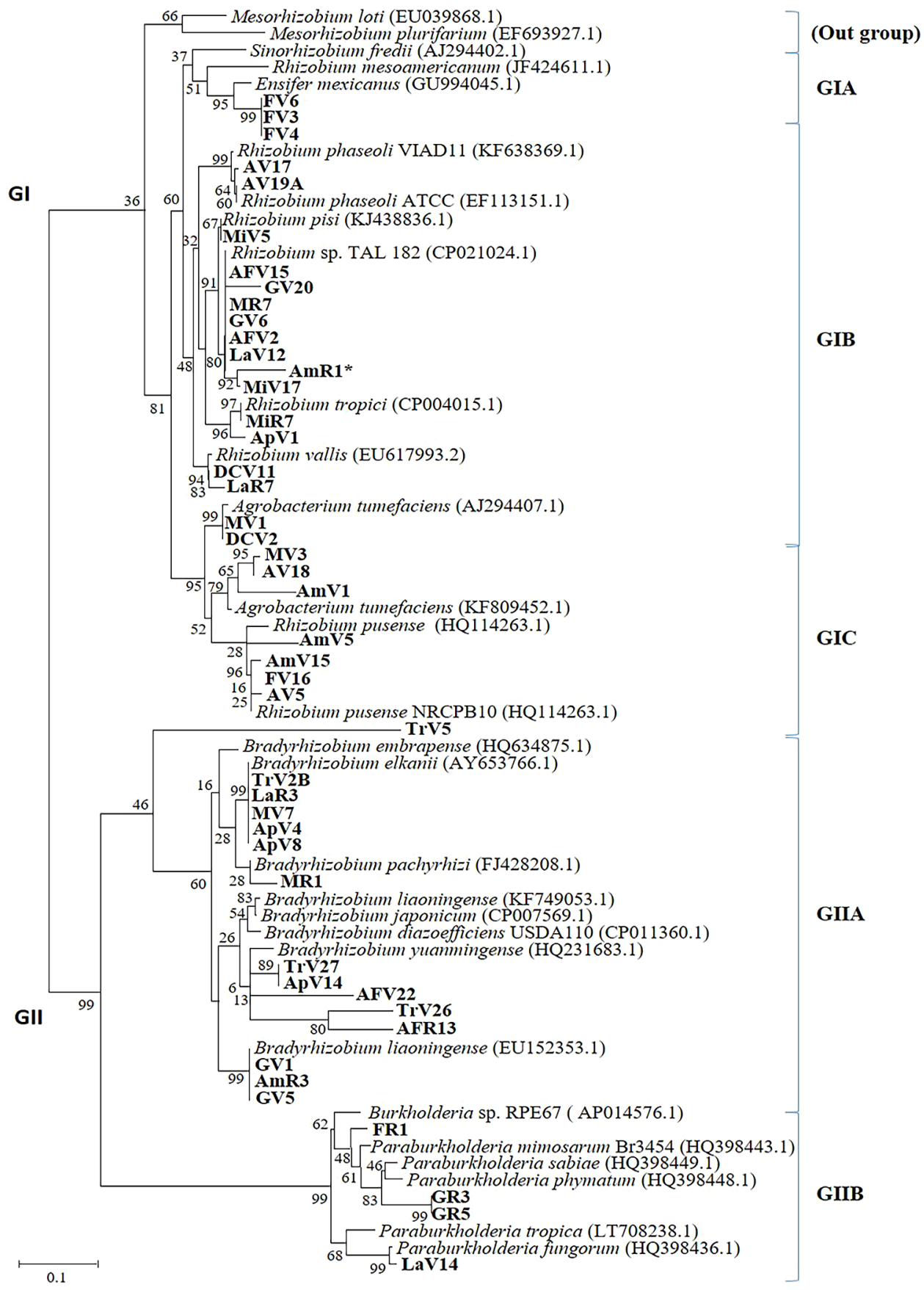

Fig. 3. Phylogenetic analysis of $a t p D$ as the housekeeping gene for Venezuelan isolates. The phylogenetic tree included Vigna-rhizobia (46 isolates) and references of $\alpha$-rhizobia and $\beta$-rhizobia (29 reference strains). The tree is based on differences in 500-bp DNA fragments. The scale bar represents substitutions per nucleotide position and each genus included the percentage of the total isolates. The isolate name includes the sampling site and associated seed variety.

strain. Based on atpD, these isolates were all confirmed to be Paraburkholderia.

Moreover, small incongruences were found between $16 \mathrm{~S}$ rRNA and atpD genes. For example, AFV2, AmR1, and MiV17 were classified into a small sub-group separate from $R$. phaseoli or $R$. etli (Fig. S1), while based on atpD sequences, isolates were reclassified as Rhizobium sp. TAC182 (Fig. 3). LaR7 (isolated from Lara) was identified as Agrobacterium/R. pusense. LaR7 was reclassified as $R$. vallis. In the Bradyrhizobium group (GIIA), three isolates (AFR13, TrV27, and TrV26) were re-grouped as $B$. yuanmingense using atpD sequences.

Phylogenetic analysis based on nodD and nifH gene sequences

A summary of the phylogenetic groups of Vigna isolates is shown in Table 3. Forty-two isolates were grouped in GI $(\alpha$-rhizobia) and the remaining isolates were $\beta$-rhizobia GII (Fig. 4). The first group was divided into the following five subgroups. GIA has a close relationship with the nodD gene that originated from $R$. leguminosarum. This group included all isolates classified previously as Agrobacterium $/ R$. 
Table 3. Summary of phylogenetic analyses and symbiotic performance of Vigna-rhizobia distributed in Venezuela

\begin{tabular}{|c|c|c|c|c|c|c|c|c|c|}
\hline $\begin{array}{l}\text { Isolate } \\
\text { name }\end{array}$ & $\begin{array}{l}\text { Site: Soil type } \\
\text { (Ecosystem) }^{\mathrm{a}}\end{array}$ & 16S rRNA/atpD & nod $\mathrm{D} \operatorname{gene}^{\mathrm{b}}$ & nifH gene & $\begin{array}{l}\text { Biomass } \\
\left(\text { DW mg plant }{ }^{-1}\right)\end{array}$ & $\begin{array}{l}\text { Root } \\
\text { nodule } \\
\text { numbers }\end{array}$ & $\begin{array}{l}\text { Root nodule } \\
\text { mass } \\
\text { (DW mg) }\end{array}$ & $\begin{array}{l}\text { ARA } \\
\left(\mu \mathrm{mol}^{-1}\right. \\
\left.\text { plant }^{-1}\right)^{\mathrm{d}}\end{array}$ & $\begin{array}{l}\text { ARA } \\
\left(\mu \mathrm{mol}^{-1}\right. \\
\left.\text { Nod }^{-1}\right)^{\mathrm{e}}\end{array}$ \\
\hline AmR1 & \multirow{5}{*}{$\begin{array}{l}\text { Amazonas: Oxisol } \\
\text { (Am-r) }\end{array}$} & Rhizobium sp. & R. leguminosarum & R.phaseoli & $1,709.0 \pm 29.0$ & $30.0 \pm 2.9$ & $3.6 \pm 0.7$ & $0.4 \pm 0.2$ & $100.0 \pm 2.9$ \\
\hline AmR3 & & Bradyrhizobium sp. & B. japonicum & Bradyrhizobium sp. & $1,258.3 \pm 25.0$ & $59.0 \pm 1.4$ & $128.3 \pm 18.1$ & $7.5 \pm 1.4$ & $57.5 \pm 1.4$ \\
\hline $\mathrm{AmV1}$ & & R. pusense & B. elkanii & B. elkanii & $823.5 \pm 33.0$ & $15.7 \pm 9.0$ & $28.2 \pm 1.6$ & $0.1 \pm 0.1$ & $2.9 \pm 9.0$ \\
\hline AmV15 & & R. pusense & B. elkanii & B. elkanii & $481.2 \pm 39.0$ & $31.7 \pm 7.0$ & $40.8 \pm 1.7$ & $0.2 \pm 0.03$ & $5.4 \pm 7.0$ \\
\hline AmV5 & & R. pusense & Bradyrhizobium sp. & B. liaoningense & $419.2 \pm 17.0$ & $13.5 \pm 1.0$ & $112.5 \pm 11.0$ & $0.0 \pm 0.0$ & 0.0 \\
\hline ApV1 & \multirow{4}{*}{$\begin{array}{l}\text { Apure: Inceptisol } \\
\text { (F) }\end{array}$} & R. tropici & R. leguminosarum & R.phaseoli & $1,779.0 \pm 102.0$ & $37.5 \pm 0.1$ & $98.8 \pm 3.8$ & $0.5 \pm 0.1$ & $5.0 \pm 0.1$ \\
\hline ApV14 & & Bradyrhizobium sp. & Bradyrhizobium sp. & B. yuanmingense & $648.7 \pm 6.5$ & $11.0 \pm 0.5$ & $32.7 \pm 10.7$ & 0.0 & 0.0 \\
\hline $\mathrm{ApV} 4$ & & B. embrapense & B. elkanii & B. embrapense & $610.2 \pm 70.0$ & $30.7 \pm 1.5$ & $43.4 \pm 1.6$ & $0.3 \pm 0.1$ & $7.5 \pm 1.5$ \\
\hline ApV8 & & Bradyrhizobium sp. & B. elkanii & B. elkanii & $521.5 \pm 100.0$ & $40.0 \pm 1.0$ & $37.0 \pm 3.0$ & $0.3 \pm 0.1$ & $8.9 \pm 1.0$ \\
\hline AV17 & \multirow{4}{*}{$\begin{array}{l}\text { Aragua: Inceptisol } \\
\text { (V-WF) }\end{array}$} & Rhizobium sp. & R. leguminosarum & R.phaseoli & $1,309.2 \pm 8.5$ & $43.5 \pm 0.5$ & $89.5 \pm 0.5$ & $1.8 \pm 0.4$ & $19.6 \pm 0.5$ \\
\hline AV18 & & Agrobacterium sp. & R. leguminosarum & B. yuanmingense & $495.3 \pm 40.0$ & $21.0 \pm 1.5$ & $32.5 \pm 2.2$ & $0.2 \pm 0.1$ & $7.0 \pm 1.5$ \\
\hline AV19A $^{\circ}$ & & Rhizobium sp. & R. leguminosarum & R. phaseoli & $289.5 \pm 26.0$ & $29.5 \pm 0.5$ & $91.1 \pm 10.0$ & $0.9 \pm 0.1$ & $9.7 \pm 3.0$ \\
\hline AV5 & & R.pusense & Bradyrhizobium sp. & B. yuanmingense & $1,242.0 \pm 220.0$ & $35.3 \pm 0.7$ & $51.7 \pm 6.0$ & $0.6 \pm 0.1$ & $12.5 \pm 0.7$ \\
\hline AFR13 & \multirow{4}{*}{$\begin{array}{l}\text { Aragua: Inceptisol } \\
\text { (V-F) }\end{array}$} & Bradyrhizobium sp. & B. elkanii & B. elkanii & $1,110.8 \pm 160.0$ & $44.0 \pm 0.8$ & $98.3 \pm 4.1$ & $1.8 \pm 0.2$ & $18.2 \pm 0.8$ \\
\hline AFV15 & & Rhizobium sp. & R. leguminosarum & R. phaseoli & $1,783.5 \pm 20.0$ & $87.7 \pm 3.0$ & $26.1 \pm 4.8$ & $2.0 \pm 0.1$ & $79.3 \pm 0.5$ \\
\hline AFV2 & & Rhizobium sp. & R. leguminosarum & R. phaseoli & $234.7 \pm 12.0$ & $16.0 \pm 0.1$ & $12.7 \pm 2.3$ & $0.5 \pm 0.2$ & $37.6 \pm 1.0$ \\
\hline AFV22 & & Bradyrhizobium sp. & Bradyrhizobium sp. & B. yuanmingense & 364 & $34.5 \pm 0.3$ & & 0.01 & $0.7 \pm 0.3$ \\
\hline DCV11 & \multirow{2}{*}{$\begin{array}{l}\text { DC: Alfisol } \\
\text { (N.P-C) }\end{array}$} & R. vallis & R. leguminosarum & R. vallis & $1,237.8 \pm 300.0$ & $52.7 \pm 9.0$ & $71.0 \pm 20.0$ & $0.01 \pm 0.03$ & $7.8 \pm 5.0$ \\
\hline DCV2 & & Agrobacterium sp. & R. leguminosarum & B. liaoningense & 90 & $45.0 \pm 1.0$ & & 0.0 & 0.0 \\
\hline FR1 & \multirow{5}{*}{$\begin{array}{l}\text { Falcon: Aridisol } \\
\text { (A-D) }\end{array}$} & Burkholderia sp. & Paraburkholderia sp. & *P. phymatum & $410.2 \pm 49.0$ & $45.0 \pm 0.1$ & $58.4 \pm 1.5$ & 0.0 & 0.0 \\
\hline FV16 & & R.pusense & B. elkanii & B. elkanii & $1,298.2 \pm 87.0$ & $22.0 \pm 0.4$ & $19.5 \pm 0.4$ & $0.7 \pm 0.1$ & $36.1 \pm 0.4$ \\
\hline FV3 & & E. mexicanus & Ensifer sp. & E. mexicanus & $1,497.8 \pm 46.0$ & $100.0 \pm 9.0$ & $117.0 \pm 15.2$ & $1.4 \pm 0.5$ & $11.8 \pm 9.0$ \\
\hline FV4 & & E. mexicanus & Ensifer sp. & B. japonicum & $709.0 \pm 97.0$ & $22.5 \pm 1.3$ & $12.0 \pm 3.6$ & $0.5 \pm 0.1$ & $44.7 \pm 1.3$ \\
\hline FV6 & & E. mexicanus & Ensifer sp. & B. japonicum & $432.1 \pm 23.0$ & $52.0 \pm 0.6$ & $67.5 \pm 20.0$ & $0.4 \pm 0.2$ & $9.2 \pm 0.6$ \\
\hline GR3 & \multirow{6}{*}{$\begin{array}{l}\text { Guárico: Vertisol } \\
\text { (S) }\end{array}$} & Paraburkholderia sp. & Paraburkholderia sp. & *P. phymatum & $446.2 \pm 46.0$ & $54.3 \pm 0.1$ & $63.0 \pm 10.1$ & 0.0 & 0.0 \\
\hline GR5 & & Paraburkholderia sp. & Paraburkholderia sp. & *P. phymatum & 32 & & & 0.0 & 0.0 \\
\hline GV1 & & Bradyrhizobium sp. & Bradyrhizobium sp. & Bradyrhizobium sp. & $1,081.7 \pm 48.0$ & $44.0 \pm 6.9$ & $57.1 \pm 22.8$ & $0.9 \pm 0.03$ & $19.3 \pm 6.9$ \\
\hline GV20 & & Rhizobium sp. & R. leguminosarum & R. phaseoli & $1,884.8 \pm 165.0$ & $59.0 \pm 0.1$ & $416.0 \pm 14.3$ & $1.7 \pm 0.7$ & $4.1 \pm 0.1$ \\
\hline GV5 & & Bradyrhizobium sp. & Bradyrhizobium sp. & Bradyrhizobium sp. & $512.8 \pm 46.0$ & $47.5 \pm 0.1$ & $60.1 \pm 16.9$ & $0.1 \pm 0.02$ & $2.4 \pm 0.1$ \\
\hline GV6 & & Rhizobium sp. & R. leguminosarum & R.phaseoli & $362.3 \pm 6.5$ & $31.3 \pm 4.1$ & $50.8 \pm 3.4$ & $0.1 \pm 0.04$ & $1.6 \pm 4.1$ \\
\hline LaR3 & \multirow{4}{*}{$\begin{array}{l}\text { Lara: Vertisol } \\
\text { (D-S) }\end{array}$} & B. embrapense & B. elkanii & B. embrapen & $972.8 \pm 15.0$ & $70.5 \pm 5.5$ & $69.3 \pm 9.6$ & $0.2 \pm 0.1$ & $2.9 \pm 2.0$ \\
\hline LaR7 & & Rhizobium sp. & B. elkanii & B. elkanii & $688.0 \pm 66.0$ & $15.0 \pm 0.2$ & $35.0 \pm 13.4$ & $0.1 \pm 0.03$ & $4.0 \pm 0.2$ \\
\hline LaV12 & & Rhizobium sp. & R. leguminosarum & R. mesoamericanun & $1,188.7 \pm 99.9$ & $33.7 \pm 1.7$ & $114.4 \pm 2.9$ & $0.4 \pm 0.1$ & $3.4 \pm 1.7$ \\
\hline LaV14 & & Paraburkholderia sp & Paraburkholderia sp & B. elkanii & $601.1 \pm 46.0$ & $9.0 \pm 0.1$ & $2.1 \pm 0.9$ & 0.0 & 0.0 \\
\hline MiR7 & \multirow{3}{*}{$\begin{array}{l}\text { Miranda: Alfisol } \\
\text { (M) }\end{array}$} & R. tropici & R. leguminosarum & R. tropici & $1,637.5 \pm 200.0$ & $95.0 \pm 4.8$ & $166.5 \pm 14.8$ & $1.0 \pm 0.1$ & $6.1 \pm 4.0$ \\
\hline MiV17 & & Rhizobium sp. & R. leguminosarum & Rhizobium sp. & $1,274.5 \pm 2.0$ & $60.0 \pm 7.9$ & $110.5 \pm 36.0$ & $1.0 \pm 0.3$ & $11.4 \pm 7.0$ \\
\hline MiV5 & & R.pisi & R. leguminosarum & R. pisi & $512.8 \pm 160.0$ & $49.0 \pm 5.0$ & $55.6 \pm 35.2$ & $0.2 \pm 0.03$ & $5.9 \pm 5.0$ \\
\hline MR7 & \multirow{5}{*}{$\begin{array}{l}\text { Mérida: Ultisol } \\
(\mathrm{A}-\mathrm{T})\end{array}$} & Rhizobium sp. & R. leguminosarum & R. phaseoli & $938.7 \pm 120.0$ & $42.0 \pm 2.8$ & $69.3 \pm 8.3$ & $0.4 \pm 0.05$ & $6.3 \pm 2.8$ \\
\hline MV1 & & Agrobacterium sp. & R. leguminosarum & Rhizobium sp. & $249.1 \pm 16.0$ & $41.0 \pm 8.0$ & $66.0 \pm 5.4$ & $0.5 \pm 0.05$ & $7.1 \pm 2.0$ \\
\hline MR1 & & Bradyrhizobium sp. & B. elkanii & B. elkanii & $409.2 \pm 46.0$ & $27.7 \pm 0.1$ & $17.3 \pm 2.3$ & $0.01 \pm 0.01$ & $0.1 \pm 1.7$ \\
\hline MV3 & & Agrobacterium sp. & R. leguminosarum & B. liaoningense & $570.9 \pm 63.0$ & $62.3 \pm 0.1$ & $55.4 \pm 4.1$ & & \\
\hline MV7 & & B. embrapense & B. elkanii & B. embrapense & $777.8 \pm 97.0$ & $37.5 \pm 0.4$ & $90.8 \pm 0.7$ & $1.0 \pm 0.2$ & $11.0 \pm 0.4$ \\
\hline $\operatorname{TrV26} 6^{\circ}$ & \multirow{4}{*}{$\begin{array}{l}\text { Trujillo: Ultisol } \\
\text { (A) }\end{array}$} & Bradyrhizobium sp. & B. japonicum & Bradyrhizobium sp. & $1,583.3 \pm 68.0$ & $31.0 \pm 9.0$ & $9.0 \pm 0.9$ & $0.4 \pm 0.2$ & $50.4 \pm 9.0$ \\
\hline $\operatorname{TrV} 27^{\circ}$ & & Bradyrhizobium sp. & Bradyrhizobium sp. & B. yuanmingense & $625.3 \pm 92.0$ & $58.0 \pm 1.2$ & $43.9 \pm 1.0$ & $0.1 \pm 0.05$ & $1.9 \pm 1.2$ \\
\hline $\operatorname{TrV} 2 B^{\circ}$ & & B. embrapense & B. elkanii & B. embrapense & $2,283.8 \pm 99.0$ & $34.5 \pm 0.2$ & $129.0 \pm 1.0$ & $1.5 \pm 0.6$ & $12.4 \pm 0.2$ \\
\hline TrV5 & & Bradyrhizobium sp. & Bradyrhizobium sp. & Bradyrhizobium sp. & $1,244.7 \pm 86.0$ & $76.7 \pm 5.0$ & $134.3 \pm 31.8$ & $3.9 \pm 1.9$ & \pm 5.0 \\
\hline
\end{tabular}

•: These strains were isolated from field conditions. Sequences were compared using Blast in GenBank. B.: Bradyrhizobium. *P: Paraburkholderia.

${ }^{a}$ V-F: valley with fertilizer; D-S: dried savanna; V-WF: valley without fertilizer; Am-r: Amazon - rainforest; A-D: aridic-like desert; A: Andes. A-

T: Andes template. N.P.-C: National Park inside the city, F: floodplain.

${ }^{\mathrm{c}}$ Nodule numbers are per plant, 4 weeks after inoculation (mean standard deviations; $n=3$ ). Control (non-inoculated) had no nodules. The plant test was performed with $V$. unguiculata 'Tuy'.

${ }_{d}^{d}$ Acetylene reduction assay (ARA). Values represent activity expressed as $\mu \mathrm{mol} \mathrm{C}_{2} \mathrm{H}_{4}{ }^{-1} \mathrm{~h}^{-1} \mathrm{~g}^{-1}$ per plant and ${ }^{\mathrm{e}} \mathrm{ARA} \mu \mathrm{mol} \mathrm{C}_{2} \mathrm{H}_{4}^{-1} \mathrm{~h}^{-1} \mathrm{~g}^{-1}$ of nodules dry weight.

Significant results based on $P<0.05$.

pusense. GIB was an outgroup. Ensifer and three isolates were grouped into GIC; these isolates were previously classified as E. mexicanus. Bradyrhizobia were classified into GID, which included all bradyrhizobia isolates, and subdivided into five subgroups according to the references as fol- lows: B. japonicum (2 isolates), B. yuanmingense (2 isolates), and B. elkanii (11 isolates). The remaining bradyrhizobia isolates included seven isolates. These isolates were previously classified as Ensifer (one isolate) and R. pusense (six isolates) (Fig. 4 and Table 3 ). The nodD sequence anal- 


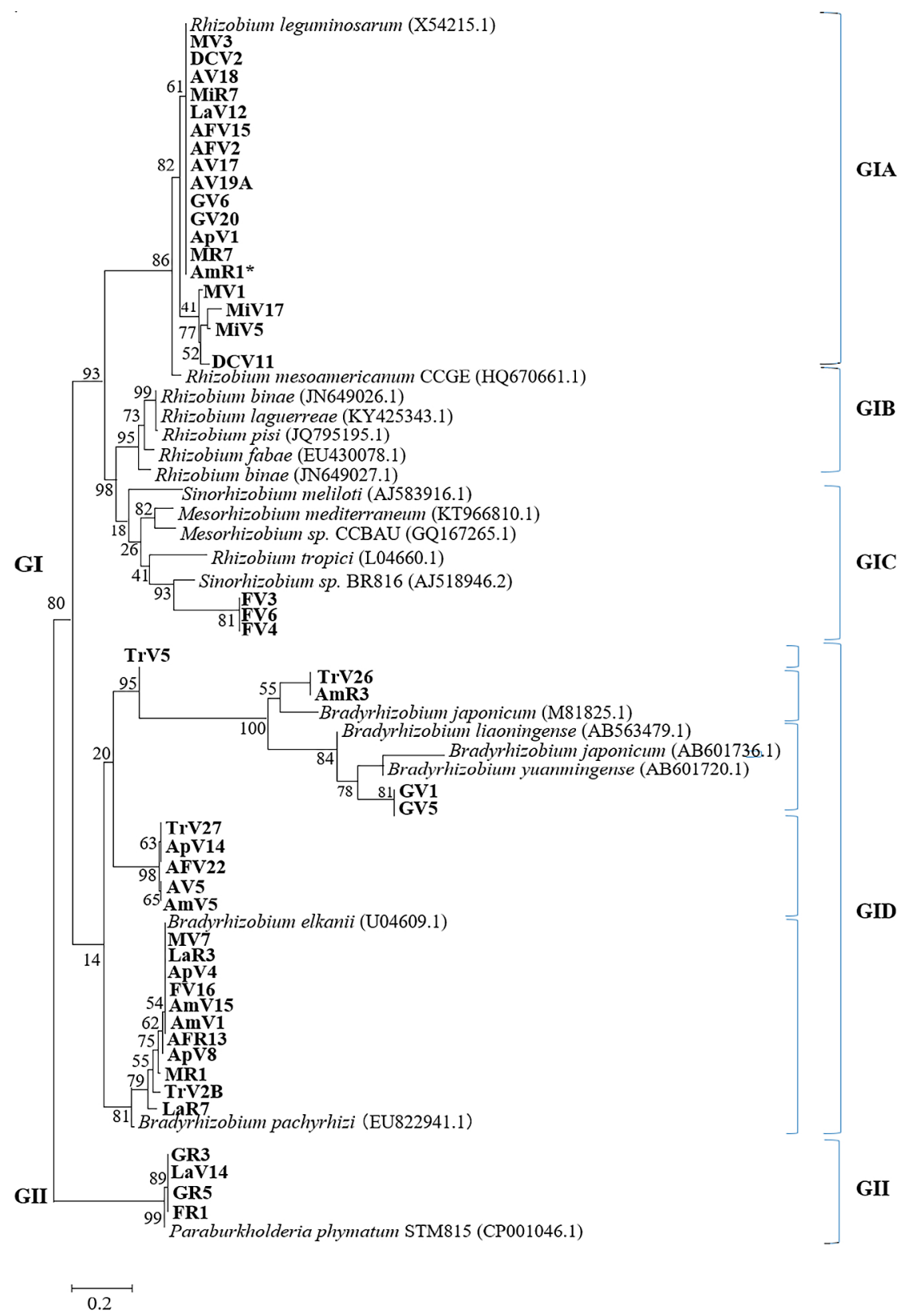

Fig. 4. Phylogenetic analysis based on nodD sequences of Venezuelan isolates. Differences are based on a 690-bp DNA fragment of the nodD gene obtained from Vigna rhizobia. The numbers at the branch nodes indicate bootstrap values (\%), based on a neighbor-joining analysis of 1,000 re-sampled datasets. The scale bar indicates substitutions per site.

ysis showed that $\beta$-rhizobia isolates were grouped as $P$. phymatum (GII). However, based on other sequences, these isolates were classified into different Paraburkholderia species.

The nifH phylogenetic analysis showed similar results to the $\operatorname{nodD}$ sequences (Fig. 5 and Table 3). All isolates were grouped into GI ( $\alpha$-rhizobia) and GII ( $\beta$-rhizobia). GI was divided into five subgroups: GIA included one isolate (FV3) and E. mexicanus. R. tropici and MiR7 were classified as GIB. The LaV12 isolate was regrouped with $R$. mesoamericanun into GIC. GID is one of the largest groups that contained 13 Venezuelan isolates. These isolates were clustered as follows: $R$. phaseoli (9 isolates), $R$. vallis (1 isolate), R. pisi (2 isolates), and R. etli bv. Phaseoli (Fig. 5).
GIE clustered all Bradyrhizobium species and 59\% of Vigna isolates from Venezuela. These groups included the same isolates in the nodD phylogenetic tree (Table 3). However, the group of $B$. japonicum included 2 isolates previously classified as Ensifer (the 16S rRNA gene). The remaining isolates were $\beta$-rhizobia (GII) classified similarly to the nodD sequences analysis (Fig. 5). Furthermore, the TrV5 isolate was classified into the Bradyrhizobium group (GIE) without any reference strains. These results suggest that TrV5 is a novel lineage according to housekeeping and symbiotic gene sequences (Table 3 ).

\section{Symbiotic performance of Venezuelan isolates}

The symbiotic performance of Vigna isolates is shown in 


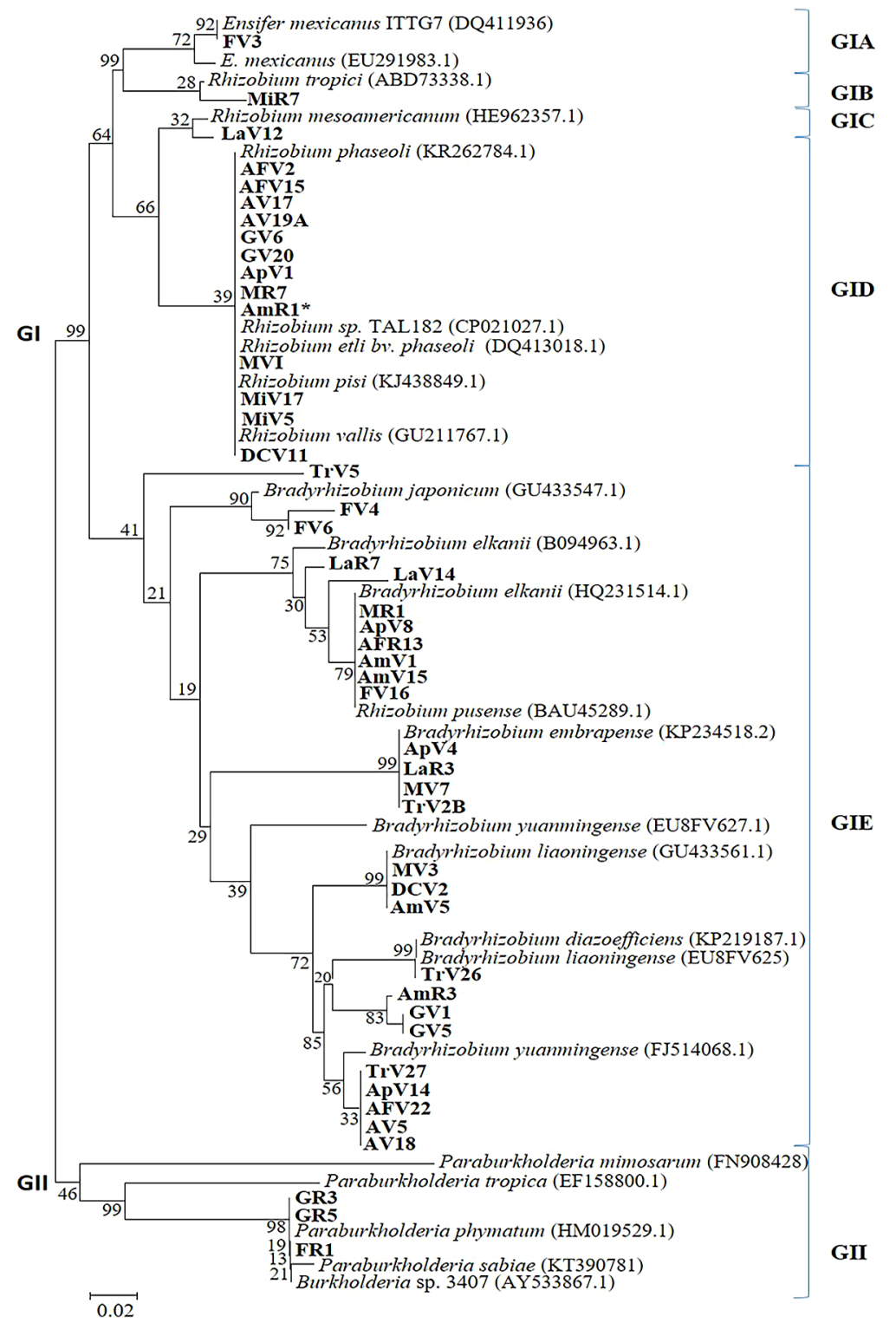

Fig. 5. Phylogenetic tree based on nifH sequences of Vigna isolates. The tree is based on differences in 750-bp DNA fragments. The numbers at the branch nodes indicate bootstrap values (\%) based on a neighbor-joining analysis of 1,000 re-sampled datasets. The scale bar indicates 0.02 changes per site.

Table 3. Forty-six isolates were inoculated onto $V$. unguiculata 'Tuy', and their effectiveness was recorded according to the interaction with the host. Root nodule numbers fluctuated between 9.0 and 100.0. FV3 showed the highest root nodule number $(100.0 \pm 9.0)$ and MiR7 the second highest (95.0 \pm 4.8$)$. These two isolates belonged to Ensifer and Rhizobium, respectively. LaV14 (Burkholderia) and ApV14 (Bradyrhizobium) showed the lowest nodulation. In the case of ARA, isolates ranged from being from ineffective to $100.0 \pm 2.9 \mu \mathrm{mol} \mathrm{C}_{2} \mathrm{H}_{4}^{-1} \mathrm{~h}^{-1} \mathrm{~g}^{-1}$ per DW of nodules. The highest performance was displayed by AmR1 (from Amazonas) classified as Rhizobium and ineffective isolates were mainly related to Burkholderia or Agrobacterium (Table 3). The root nodules developed by Rhizobium isolates exhibited slightly higher ARA than those by other strains, such as Agrobacterium and some Paraburkholderia isolates. All isolates had a significantly larger biomass than the non-inoculated control $(290.1 \pm 25.0$ mg plant ${ }^{-1}$ ) by Dunnett's tests. The exceptions were AFV2, AV19A, GR5, and MV1, which showed no significant differences. The highest biomass belonged to TrV2B with $2,283.8 \pm 100.0 \mathrm{mg}$ plant $^{-1}$. The isolate TrV2B was classified as Bradyrhizobium (Table 3). Additionally, no relationship was observed between nodule numbers and ARA by Tukey's test (data not shown). However, a correlation was found between ARA plant ${ }^{-1}$ and biomass in comparisons of all samples (Table 3). Furthermore, the specific linear correlation (data not shown) showed a moderate correlation between biomass and ARA plant ${ }^{-1}$ because several strains did not have a relationship with these parameters, such as ApV1, AFV2, and LaV12 (Table 3). 


\section{Discussion}

Vigna-rhizobia isolation, distribution, and physiological responses

The nodulation activity, geographical distribution, and diversity of rhizobia were mainly related to the history of legume cultivation and environmental factors, such as climate conditions and soil parameters, in the present study. The distribution of Vigna-rhizobia in Venezuela based on housekeeping genes revealed that $\alpha$-rhizobia was dominant and widely distributed in Venezuelan soils. This result suggested that distribution was affected by the cultivation history of native or cultivated legumes such as Vigna. Cuadrado et al. (2009) reported that $V$. unguiculata was mainly nodulated by Rhizobium, Bradyrhizobium, and Mesorhizobium in Colombia. Our results are consistent with these findings, except for Mesorhizobium strains. Zhang et al. (2008) showed that in subtropical areas of China, the dominant group associated with $V$. unguiculata and $V$. radiata was Bradyrhizobium. Moreover, in Japan, Akatsu et al. (2014) isolated Ensifer and Rhizobium strains associated with $V$. marina and $V$. radiata from sandy soils.

As expected, Inceptisol (Aragua, Valley) showed a high rate of nodulation and Venezuelan rhizobia with a dominance of Rhizobium over Bradyrhizobium, and this may be attributed to the optimal agroecological conditions and continuous bean cultivation in these sites. Similarly, the Rhizobium group was dominant in Alfisol. However, the absence of nodulation in DC soils may be related to the lack of Vigna cultivation history, climate, and the combination of acidic $\mathrm{pH}$ and $\mathrm{Al}$ (Casanova, 2005). Furthermore, Venezuelan isolates classified as Rhizobium suggested a close relationship with $R$. phaseoli and $R$. etli. For example, AFV2 was classified as $R$. phaseoli, Rhizobium sp. TAC182 ${ }^{\mathrm{T}}$, or $R$. leguminosarum bv. phaseoli ${ }^{\mathrm{T}}$. Rhizobium sp. TAC $182^{\mathrm{T}}$ was previously related to $R$. phaseoli (Santamaría et al., 2017). These Rhizobium strains were correlated mainly with Phaseolus species and isolated from Latin American countries. Several isolates were related to $R$. phaseoli VIAD11 ${ }^{\mathrm{T}}$, which had been found in Meso-America (Mexico), through Central-America (Dominican Republic), to South-America (Argentina, Ecuador), and linked with Europe through Spain (Díaz-Alcántara et al., 2014), and now in Venezuela with distribution in savannas, valleys and mountain areas. Accordingly, Marquina et al. (2011) described Rhizobium strains isolated from the Venezuelan root nodules of Leucaena, which survived at $2 \% \mathrm{NaCl}$.

Falcón showed a good rate of nodulation. Therefore, Vigna-rhizobia obtained from these locations were expected to be more stress-tolerant than other areas (Graham et al., 1981; Graham, 1992). These Venezuelan isolates and reference strains were isolated under similar environmental conditions, such as temperatures of approximately $40^{\circ} \mathrm{C}$, arid or semi-arid ecosystems with sandbanks, and Aridisol as the soil type. E. mexicanus ITTG-R7T (NR115768.1) was taken from Tuxtla in Mexico (Lloret et al., 2007), while in Venezuelan, they were from Falcón. Venezuelan isolates (FV3, $\mathrm{FV} 4$, and FV6) and E. mexicanus reported by Lloret et al. (2007) strongly suggested that these Ensifer strains origi- nated from American hosts, with a specific distribution under high temperatures and water stress conditions. Regarding Vigna, Akatsu et al. (2014) reported Ensifer strains with salinity tolerance under more than $3.5 \% \mathrm{NaCl}$ that also grew well at $45^{\circ} \mathrm{C}$. The salinity tolerance of isolates suggested a slight tendency according to the origin of isolates.

Isolates related to the genus Bradyrhizobium were dominant in Ultisol (Trujillo, Andes). These isolates showed $\mathrm{pH}$ tolerance, which suggests that $\mathrm{Al}$ and $\mathrm{Mn}$ toxicities as well as $\mathrm{Ca}^{2+}$ deficiencies are often associated with low soil $\mathrm{pH}$ (Graham et al., 1981; Rodríguez and López, 2009; Guimarães et al., 2012; Artigas et al., 2019). In Venezuela, these types of soils are common in traditional cropping systems, such as in Trujillo where $\mathrm{CaCO}_{3}$ is added before and during Vigna cultivation (Casanova, 2005). Silva et al. (2014) reported that in the Brazilian rainforest, Vigna was mainly nodulated by Bradyrhizobium, which is consistent with the present results. However, the isolates classified as Ensifer and Bradyrhizobium showed more biogeographic specificity than Rhizobium.

On the other hand, some isolates were related to $\beta$ rhizobia and mainly associated with $V$. radiata, which is in contrast to previous findings (Zhang et al., 2008; Risal et al., 2012; Akatsu et al., 2014; Bejarano et al., 2014; Andrews and Andrews, 2017). Paraburkholderia isolates were obtained from nutrient-deficient soils, such as Guárico, Lara, and Falcón, as reported previously (Ferreira et al., 2012; Radl et al., 2014). Moreover, Guárico and Falcón have no previous cultivation history of Vigna. In tropical soils, a reduction in the rhizobial population size due to Vigna seeds occurred under successive stress nutrient conditions (Graham et al., 1981). In Brazil, $\beta$-rhizobia has been described as a symbiont of $V$. unguiculata in semi-arid and Amazonian soils (Guimarães et al., 2012; Radl et al., 2014), but not in other countries, such as Africa and Asia (Sarr et al., 2011). Venezuelan Paraburkholderia was identified by biogeographic relationship and soil fertility problems (Artigas et al., 2019). In Latin-American countries, such as Mexico, Brazil, and Uruguay, Burkholderia has mainly been associated with Mimosa species (Bontemps et al., 2016; Platero et al., 2016). Some Burkholderia species have been reported as acid-tolerant and commonly distributed in low nutrient soils (Graham, 1992; De Oliveira-L et al., 2015; Bontemps et al., 2016; Platero et al., 2016; Artigas et al., 2019).

The optimal season for $V$. unguiculata and $V$. radiata cultivation significantly differs according to topographic and climatic regions in Venezuela. In the case of Vigna legumes, $V$. unguiculata is slightly more promiscuous than $V$. radiata, principally under field conditions. In the present study, no relationship was observed between strains isolated from both Vigna species and $\mathrm{pH}$ tolerance. However, $\mathrm{pH}$ conditions affected symbiosis, such as rhizobial growth, decreased nodule initiation, and impaired nodule function (Graham et al., 1981; Casanova, 2005; Guimarães et al., 2012). Additionally, the different $\mathrm{pH}$ tolerance of rhizobia influenced strain competitiveness (Sylvester-Bradley, 1983; Singh et al., 1997). All factors were linked to $\mathrm{N}_{2}$ fixation in different ways and legume growth. 
Legumes belonging to the Phaseoleae tribe, such as $V$. unguiculata, are nodulated by rhizobia from different genera across $\alpha$ - and $\beta$-Proteobacteria (Andrews and Andrews, 2017). Since $V$. unguiculata is indigenous to the South Africa Transvaal region, our results suggest that this legume is adapted for nodulation by different rhizobia species in Venezuelan soil (Velázquez et al., 2010; Córdova-Sanchéz et al., 2011; Parra, 2013; Chidebe et al., 2018). In the present study, a new premise was suggested about these rhizobia, which could have a tropical or subtropical origin because the isolation was from Phaseoleae legumes. One possibility may be that the introduction, variation, and cultivation history of legumes in different regions forced the evolution of several root-nodulating bacteria, which may form symbioses under different conditions (Graham, 1992; Barcellos et al., 2007; Córdova-Sanchéz et al., 2011; Parra, 2013; Chidebe et al., 2018). Furthermore, limited information is currently available on the diversity, distribution, and ecology of endemic Venezuelan legume symbionts. Despite their diversity and biotechnological potential, most of the bacterial strains isolated from Venezuelan soil remain uncharacterized.

\section{Symbiotic genes and horizontal symbiotic gene transfer}

The distribution of nod genes depends on the relationship between or co-evolution of rhizobia and cultivars. DíazAlcántara et al. (2014) reported that Mesoamerican cultivars were associated with rhizobia that carried a nod allele originating in Mexico (North American), while Andean cultivars carried a nod allele from Ecuador (South America). These alleles could be identified according to the cultivar region of origin, e.g., Colombian and Brazilian rhizobia possessed the same nod allele as rhizobia associated with beans in Ecuador. Therefore, Venezuelan isolates appear to carry a nodD allele that is related to the ecosystem and cultivar. Santamaría et al. (2017) reported that several unrelated strains, such as Rhizobium sp. TAC $182^{\mathrm{T}}$, have a pSyms plasmid that may converge or diverge toward environmental conditions and the nodulation of common hosts. This may explain the results with several strains between Rhizobium isolates and the reason why the strains carrying this allele that have been distributed into the Caribbean from seedlings-beans of South America (Díaz-Alcántara et al., 2014).

Furthermore, previous studies reported that several symbiotic genes of Mesorhizobium were transferred from a symbiotic strain to different genera of rhizobia in the field (Sullivan and Ronson, 1998). Other studies demonstrated the horizontal transfer of symbiotic genes among an inoculant (B. japonicum) and indigenous Brazilian rhizobia, such as B. elkanii and E. fredii, in savanna soils (Barcellos et al., 2007). This is consistent with the present results showing the existence of nod and nif genes between $\alpha$-rhizobia genera. The relationship between Agrobacterium and Rhizobium may explain horizontal symbiotic gene transfer, in which the adaptation and co-evolution of legume-rhizobia interactions is an important factor (Paludosi and Ng, 1997; Velázquez et al., 2010; Chidebe et al., 2018). Furthermore, Quinto et al. (1985) reported three different regions in the symbiotic plasmid of $R$. phaseoli, which contained the com- plete coding sequence of the nif gene. The nucleotide sequences of the three nif genes were identical and functional copies (Quinto et al., 1985). However, this finding implies that at least 2 of the reiterated genes were functionally expressed after transfer, which may have occurred between some of our isolates.

In the case of $\beta$-rhizobia, Venezuelan Paraburkholderia displayed nodulation, whereas ARA was not detected, which is consistent with previous findings in Brazil (Ferreira et al., 2012; Silva et al., 2014). Brazilian isolates related to $P$. fungorum were found in Amazonian soil (Brazil) using $P$. vulgaris (Ferreira et al., 2012; Silva et al., 2014), and explains the result obtained with LaV14 suggesting the presence of horizontal gene transfer between $\alpha$ - and $\beta$-rhizobia isolates in Venezuelan soils. B. elkanii was previously reported to be widely distributed in tropical soils (Barcellos et al., 2007; Radl et al., 2014). The appearance of nitrogen fixation genes from B. elkanii in Paraburkholderia suggests the existence of the horizontal gene transfer of symbiotic islands between Bradyrhizobium and Paraburkholderia (Artigas et al., 2019). However, a comparative molecular analysis is needed to confirm this.

\section{Symbiotic function and plant growth promotion}

The symbiotic performance of Vigna isolates and their effectiveness varied from ineffective to high plant growth promotion. Consequently, a relationship was not observed between nodulation and nitrogen fixation or biomass. Incompatibility between rhizobia and Vigna cultivars has been reported, for example, $V$. radiata 'KPS1' is incompatible with $B$. elkanii USDA61, resulting in ineffective nodulation, whereas this type of rhizobia is compatible with $V$. mungo (Nguyen et al., 2018). These findings may explain the ineffectiveness observed in some Bradyrhizobium strains (e.g., ApV14, AFV22, and TrV27) isolated from $V$. unguiculata at different sampling sites and inoculated on the same plant host. Moreover, the positive correlation between ARA (per plant) and biomass indicates that the number or mass of root nodules is an important factor for the utilization of energy by plants and the efficiency of strains (Cuadrado et al., 2009).

Additionally, the results obtained for several $\alpha$-rhizobia (e.g., TrV2B) suggested that Venezuelan-rhizobia promoted plant growth by mechanisms other than nitrogen fixation, such as phytohormone production and phosphorus solubilization. Rodríguez and López (2009) inoculated $V$. unguiculata with plant growth-promoting bacteria (such as Bacillus megaterium and non-nodulating Burkholderia) in combination with a reduced amount of basal fertilizer $(\mathrm{N}, \mathrm{P}$, $\mathrm{K}$,) in Ultisol (savanna, Guárico). The findings obtained showed that the biomass increased and a high capacity for rhizobia colonization was observed (Rodríguez and López, 2009), suggesting that native rhizobia contribute to the high biomass or healthy crop production. In the present study, two isolates had a slightly higher biomass and ARA (AmR1 and AFV15); one isolated without a Vigna cultivation history in Amazonas (rainforest), and the other with a legume cultivation history from Aragua (valley, with fertilization). Additionally, these isolates appeared to be genetically stable at symbiotic genes, and root nodule masses were lower than 
those in other samples, such as GV20, which reflected energy use by the plant. Accordingly, AFV15 showed several proprieties, such as fast growth and tolerance to high $\mathrm{Al}$ concentrations under acidic $\mathrm{pH}$ conditions. These results indicate the potential of these isolates as effective inoculants for Vigna plants under abiotic stress conditions.

In conclusion, the present results contribute to our understanding of the distribution and environmental conditions related to two Vigna species and their symbionts in Venezuela. In the present study, important issues that may affect rhizobial diversity and competitiveness were highlighted, such as crop production, soil conditions, and other factors. Additionally, the results obtained suggest that undisturbed soil covered with native vegetation may have a higher diversity of rhizobia. Furthermore, this study confirmed that an uncommon and understudied group of rhizobia (genus Paraburkholderia) was associated with Vigna plants in Venezuela. Some isolates showed different nifH and nodD alleles than expected from the housekeeping gene analysis, suggesting horizontal gene transfer. The highest symbiotic performance of AFV15 (Rhizobium) in combination with good physiological responses indicates its potential as a suitable novel inoculant for Vigna under abiotic stress conditions or possibly in combination with other K or P fertilizers. However, further field studies are needed to confirm the effectiveness of AFV15 as a Vigna inoculant.

\section{Acknowledgements}

The authors thank the Special Research Fund of the Institute of Global Research Innovation at Tokyo University of Agriculture and Technology (GIR-TUAT, Japan). This work was also supported by Grants-in-Aid for Scientific Research (A): $18 \mathrm{H} 04148$ (2018 2021) from the Japanese Society for the Promotion of Science (JSPS). The authors thank Lopez Marisol† and the staff of the National Laboratory of Biofertilizer (Instituto Nacional de Investigaciones Agricola, CENIAP-INIA, Venezuela).

\section{References}

Akatsu, T., Ishikawa, H., Sano, N., Norihiko, T., Ohkama-Ohtsu, N., Kanekatsu, K., and Yokoyama, T. (2014) Evaluation of genetic strains of root nodule bacteria collected from Ishigaki and Iriomote islands and its salt tolerance mechanism. Proc Annu Meet Jpn Assoc Soil Microorg 68: 48.

Allen, O.N., and Allen, E.K. (1981) The Leguminosae: A Source Book of Characteristics Uses and Nodulation. Madison, USA: University of Wisconsin Press.

Andrews, M., and Andrews, M.E. (2017) Specificity in legume-rhizobia symbioses. Int J Mol Sci 18: 705.

Artigas, R.M.D., España, M., Aguirre, C., Kojima, K., Ohkama-Ohtsu, N., Sekimoto, H., and Yokoyama, T. (2019) Burkholderia and Paraburkholderia are predominant soybean rhizobial genera in Venezuelan soils in different climatic and topographical regions. Microbes Environ 34: 43-58.

Barcellos, F.G., Menna, P., Da Silva-Batista, J.S., and Hungria, M. (2007) Evidence of horizontal transfer of symbiotic genes from a Bradyrhizobium japonicum inoculant strain to indigenous diazotrophs Sinorhizobium (Ensifer) fredii and Bradyrhizobium elkanii in a Brazilian Savannah soil. Appl Environ Microbiol 73: 2635-2643.

Bejarano, A., Ramirez-Bahena, M.H., Velazquez, E., and Peix, A. (2014) Vigna unguiculata is nodulated in Spain by endosymbionts of Genisteae legumes and by a new symbiovar (Vignae) of the genus Bradyrhizobium. Syst Appl Microbiol 37: 533-540.
Bontemps, C., Rogel, M.A., Wiechmann, A., Mussabekova, A., Moody, S., Simon, M.F., et al. (2016) Endemic Mimosa species from Mexico prefer alphaproteobacterial rhizobial symbionts. New Phytol 209: 319-333.

Casanova, O.E.F. (2005) Introducción a la ciencia del suelo. Ed. Consejo de Desarrollo Humanístico. Venezuela: Universidad Central de Venezuela.

Chidebe, I.N., Jaiswal, S.K., and Dakora, F.D. (2018) Distribution and phylogeny of microsymbionts associated with cowpea (Vigna unguiculata) nodulation in three agroecological regions of Mozambique. Appl Environ Microbiol 84: e01712-17.

Córdova-Sanchéz, S., Castelán-Estrada, M., Salgado-García, S., PalmaLópez, J., Vera-Núñez, J., Peña-Cabriales, J., et al. (2011) Fijación biológica de nitrógeno por tres fabáceas (Leguminosae) en suelos ácidos de Tabasco, México. Avan Inv Agro 15: 31-50.

Cuadrado, B., Rubio, G., and Santos, W. (2009) Caracterización de cepas de Rhizobium y Bradyrhizobium (con habilidad de nodulación) seleccionados de los cultivos de fríjol caupi (Vigna unguiculata) como potenciales bioinóculos. Rev Colomb Cienc Quim-Farm 38: 78-104.

De Oliveira-L, S.M., De Sousa, P.M., Marra, L.M., Ferreira, P.A.A., and De Souza Moreira, F.M. (2015) Burkholderia fungorum promotes common bean growth in a dystrophic oxisol. Ann Microbiol 65: $1825-1832$.

Díaz-Alcántara, C.A., Ramírez-Bahena, M.H., Mulas, D., García-Fraile, P., Gómez-Moriano, A., Peix, A., et al. (2014) Analysis of rhizobial strains nodulating Phaseolus vulgaris from Hispaniola Island, a geographic bridge between Meso and South America and the first historical link with Europe. Syst Appl Microbiol 37: 149-156.

Doyle, J.J. (1994) Phylogeny of the legume family: an approach to understanding the origins of nodulation. Annu Rev Ecol Evol Syst 25: $325-349$.

Ferreira, P.A.A., Bomfeti, C.A., Soares, B.L., and De Souza Moreira, F.M. (2012) Efficient nitrogen-fixing Rhizobium strains isolated from Amazonian soils are highly tolerant to acidity and aluminium. World J Microbiol Biotechnol 28: 1947-1959.

Gaunt, M.W., Turner, S.L., Rigottier-Gois, L., Lloyd-Macgilp, S.A., and Young, J.P. (2001) Phylogenies of atpD and recA support the small subunit rRNA-based classification of rhizobia. Int J Syst Evol Microbiol 51: 2037-2048.

Graham, P.H., Apolitano, C., Ferrera, R., Halliday, J., Lepiz, R., Menéndez, D., et al. (1981) The International Bean Inoculation Trail (IBIT): Results for the 1978-1979 Trial. In Biological nitrogen fixation technology for tropical agriculture. Graham, P.H., and Harris, S.C. (eds). Cali, Colombia: CIAT, pp. 223-229.

Graham, P.H. (1992) Stress tolerance in Rhizobium and Bradyrhizobium, and nodulation under adverse soil conditions. Can J Microbiol 38: $475-484$.

Guimarães, A.A., Jaramillo, P.M.D., Nóbrega, R.S.A., Florentino, L.A., Silva, K.B., and De Moreira, F.M.S. (2012) Genetic and symbiotic diversity of nitrogen-fixing bacteria isolated from agricultural soils in the Western Amazon by using cowpea as the trap plant. Appl Environ Microbiol 78: 6726-6733.

Hsu, P.H. (1963) Effect of initial pH, phosphate, and silicate on the determination of aluminum with aluminon. Soil Sci 96: 230-238.

Jones, J.B. (2001) Laboratory Guide for Conducting Soil Tests and Plant Analysis. Washington, USA: CRC Press.

Laguerre, G., Nour, S.M., Macheret, V., Sanjuan, J., Drouin, P., and Amargar, N. (2001) Classification of rhizobia based on nodC and nifH gene analysis reveals a close phylogenetic relationship among Phaseolus vulgaris symbionts. Microbiol 147: 981-993.

Lambrides, C.J., and Godwin, I.D. (2007) Mungbean. In Genome Mapping and Molecular Breeding in Plants, Volume 3: Pulses, Sugar and Tuber Crops, Kole, C. (ed). Heidelberg, Germany: Springer-Verlag, pp. 69-90.

Li, J., Lis, K.E., and Timko, M.P. (2009) Molecular genetics of racespecific resistance of cowpea to Striga gesnerioides (Willd.) Pest Manage Sci 65: 520-527.

Lloret, L., Ormeno-Orrillo, E., Rincon, R., Martínez-Romero, J., RogelHernández, M.A., and Martínez-Romero, E. (2007) Ensifer mexicanus sp. nov. a new species nodulating Acacia angustissima (Mill.) Kuntze in Mexico. Syst Appl Microbiol 30: 280-290. 
Lu, Y.L., Chen, W.F., Han, L.L., Wang, E.T., and Chen, W.X. (2009) Rhizobium alkalisoli sp. nov., isolated from Caragana intermedia growing in saline-alkaline soils in the north of China. Int J Syst Evol Microbiol 59: 3006-3011.

Marquina, M.E., González, N.E., and Castro, Y. (2011) Caracterización fenotípica y genotípica de doce rizobios aislados de diversas regiones geográficas de Venezuela. Rev Biol Trop 59: 1017-1036.

Nguyen, H.P., Ratu, S., Yasuda, M., Göttfert, M., and Okazaki, S. (2018) InnB, a Novel Type III effector of Bradyrhizobium elkanii USDA61, controls symbiosis with Vigna species. Front Microbiol 9: 31-55.

Paludosi, S., and Ng, N.Q. (1997) Origin, taxonomy, and morphology of Vigna unguiculata (L.) Walp. In Advances in Cowpea Research. Singh, B.B., Mohan-Raj, D.R., Dashiell, K.E., and Jackai, L.E.N. (eds). Ibadan, Nigeria: International Institute of Tropical Agriculture (IITA) and Japan International Research Center for Agricultural Sciences (JIRCAS), pp. 1-12.

Parra, Z.C.T. (2013) Efecto de Rhizobium y micorrizas arbusculares en el desarrollo de Cajanus cajan en presencia de abonos verdes, en suelos naturales de la localidad de Espino estado Guárico. Scientiarum Magister Dissertation. Caracas, Venezuela: Graduate School of Soil Sciences. Universidad Central de Venezuela.

Platero, R., James, E.K., Rios, C., Iriarte, A., Sandes, L., Zabaleta, M., et al. (2016) Novel Cupriavidus strains isolated from root nodules of native Uruguayan Mimosa species. Appl Environ Microbiol 82: $3150-3164$.

Quinto, C., De la Vega, H., Flores, M., Leemans, J., Cevallos, M.A., Pardo, M.A., et al. (1985) Nitrogenase reductase: a functional multigene family in Rhizobium phaseoli. Proc Natl Acad Sci U S A 82: $1170-1174$.

Radl, V., Simões-Araújo, J.L., Leite, J., Passos, S.R., Martins, L.M.V., Xavier, G.R., et al. (2014) Microvirga Vignae sp. nov., a root nodule symbiotic bacterium isolated from cowpea grown in semi-arid Brazil. Int J Syst Evol Microbiol 64: 725-730.

Ren, D.W., Chen, W.F., Sui, X.H., Wang, E.T., and Chen, W.X. (2011) Rhizobium Vignae sp. nov., a symbiotic bacterium isolated from multiple legume species. Int J Syst Evol Microbiol 61: 580-586

Risal, C.P., Djedidi, S., Dhakal, D., Ohkama-Ohtsu, N., Sekimoto, H., and Yokoyama, T. (2012) Phylogenetic diversity and symbiotic functioning in mungbean (Vigna radiata L. Wilczek) bradyrhizobia from contrast agro-ecological regions of Nepal. Syst Appl Microbiol 35: $45-53$.

Rodríguez, B., and López, M. (2009) Evaluation of the biological fertilization on cowpea with nativa Rhizobium strains isolated from an Ultisol in landplane Guárico State. Agron Trop 59: 381- 386.

Santamaría, R.I., Bustos, P., Pérez-Carrascal, O.M., Miranda-Sánchez, F., Vinuesa, P., Martínez-Flores, I., et al. (2017) Complete genome sequences of eight Rhizobium symbionts associated with common bean (Phaseolus vulgaris). Genome Announc 5: e00645-17.

Sarr, P.S., Yamakawa, T., Saeki, Y., and Guisse, A. (2011) Phylogenetic diversity of indigenous cowpea bradyrhizobia from soils in Japan based on sequence analysis of the 16S-23S rRNA internal transcribed spacer (ITS). Syst Appl Microbiol 34: 285-292.
Silva, F.V., De Meyer, S.E., Simoes-Araujo, J.L., da Costa Barbe, T., Xavier, G.R., O'Hara, G., et al. (2014) Bradyrhizobium manausense sp. nov., isolated from effective nodules of Vigna unguiculata grown in Brazilian Amazonian rainforest soils. Int J Syst Evol Microbiol 64: 2358-2363.

Singh, B.B., Mohan-Raj, D.R., Dashiell, K.E., and Jackai, L.E.N. (1997) Physiology and Agronomy. In Advances in Cowpea Research. Singh, B.B., Mohan-Raj, D.R., Dashiell, K.E., and Jackai, L.E.N. (eds). Ibadan, Nigeria: International Institute of Tropical Agriculture (IITA) and Japan International Research Center for Agricultural Sciences (JIRCAS), pp. $75-147$.

Somasegaran, P., and Hoben, J.H. (1994) Handbook for Rhizobia: Methods in Legume-Rhizobium Technology. New York, USA: Springer-Verlag.

Sullivan, J.T., and Ronson, C.W. (1998) Evolution of rhizobia by acquisition of a $500-\mathrm{kb}$ symbiosis island that integrates into a phetRNA gene. Proc Natl Acad Sci U S A 95: 5145-5149.

Sylvester-Bradley, R., Ayarza, M.A., Mendez, J.E., and Moriones, R. (1983) Use of undisturbed soil cores for evaluation of Rhizobium strains and methods for inoculation of tropical forage legumes in a Colombian Oxisol. Plant Soil 74: 237-247.

Tamura, K., Stecher, G., Peterson, D., Filipski, A., and Kumar, S. (2013) MEGA6: molecular evolutionary genetics analysis version 6.0. Mol Biol Evol 30: 2725-2729.

Timko, M.P., Ehlers, J.D., and Roberts, P.A. (2007) Cowpea. In Genome Mapping and Molecular Breeding in Plants. Volume 3: Pulses, Sugar and Tuber Crops, Kole, C. (ed). Heidelberg, Germany: Springer-Verlag, pp. 49-67.

Vásquez, A.M. (2014) Efecto de concentraciones de fósforo, níquel y sílice en el crecimiento, nodulación y fijación simbiótica de $N_{2}$ en Vigna unguiculata (L) Walp, Vigna unguiculata ssp sesquispedalis y V. radiata. PhD Thesis. Caracas, Venezuela: Graduate School of Sciences. Universidad Central de Venezuela.

Velázquez, E., Valverde, A., Rivas, R., Gomis, V., Peix, Á., Gantois, I., et al. (2010) Strains nodulating Lupinus albus on different continents belong to several new chromosomal and symbiotic lineages within Bradyrhizobium. Antonie van Leeuwenhoek 97: 363-376.

Vincent, J.M. (1970) A Manual for the Practical Study of Root-Nodule Bacteria (IBP handbook no. 15). Oxford, UK: Blackwell Scientific Publications.

Vinuesa, P., Silva, C., Lorite, M.J., Izaguirre-Mayoral, M.L., Bedmar, E.J., and Martínez-Romero, E. (2005) Molecular systematics of rhizobia based on maximum likelihood and Bayesian phylogenies inferred from $r r s, a t p D, r e c A$ and nifH sequences, and their use in the classification of Sesbania microsymbionts from Venezuelan wetlands. Syst Appl Microbiol 28: 702-716.

Zhang, Y.F., Wang, E.T., Tian, C.F., Wang, F.Q., Han, L.L., Chen, W.F., and Chen, W.X. (2008) Bradyrhizobium elkanii, Bradyrhizobium yuanmingense and Bradyrhizobium japonicum are the main rhizobia associated with Vigna unguiculata and Vigna radiata in the subtropical region of China. FEMS Microbiol 285: 146 -154. 